\title{
Current state and problems of alternative energy development in the world
}

\author{
Bakhyt Baitanayeva ${ }^{1 *}$, Aimankul Yerezhepova ${ }^{1}$, Biken Nurmanova $^{1}$, Gulmira \\ Andabayeva $^{1}$ \\ ${ }^{1}$ al-Farabi Kazakh National University, Almaty, Kazakhstan
}

\begin{abstract}
The article is devoted to the current state and analysis of factors affecting the use of alternative energy sources on a global scale. There is a constant growth in volumes energy consumption, which is associated with the stability of the global economy, increasing costs for heating and cooling in various parts of the world. At the same time in the most densely populated areas (China, India), coal accounts for up to $80 \%$ of the energy balance, which leads to an increase in $\mathrm{CO} 2$ emissions. In this regard, the article notes the need to switch to the use of alternative energy sources (wind, solar, hydro, geothermal and biomass, nuclear energy). The article analysis the current state of energy sources in developed countries according to statistics for 2018. The authors concludes that the growth rate of renewable energy resources is insufficient, despite their advantage over traditional sources. In this regard, the factors affecting the efficiency of renewable energy sources were summarized. In addition, the article identifies barriers that prevent the acceleration of the rate of replacing traditional energy sources with RES. At the same time, state support measures and relevant legislative acts play a special role in stimulating and attracting the necessary investments.
\end{abstract}

Keywords: $\mathrm{CO}_{2}$ emissions, alternative energy, renewable energy, incentive measures, barriers

\section{Introduction}

The development of energy in modern conditions is characterized by an increase in the share of alternative energy sources, especially solar and wind energy. According To the international renewable energy Agency (IRENA), the use of RES is accompanied by a multiplier effect: doubling the share of RES in the world energy balance by 2030 will lead to GDP growth by $0.6-1.1 \%$ ( $\$ 1.3$ trillion.), as well as wealth will increase by $3.7 \%$, employment in the renewable energy sector will increase by $6 \%$ annually.

In 2018, the share of alternative energy in the global energy sector was $35.3 \%$ (including nuclear energy). At the same time, the high share of coal in electricity production leads to significant $\mathrm{CO}_{2}$ emissions, which reached a historical maximum in 2018 (33.1 MT). This

${ }^{*}$ Corresponding author: baytanaeva2007@ rambler.ru 
process leads to global warming and climate change, which are expressed in sea level rise and natural disasters.

In this regard, the study of issues related to global trends in the use of alternative energy sources, analysis of factors that affect their development, as well as barriers to their wider distribution is relevant.

\section{Results and Discussion}

In today's globalized world, regions and countries depend on each other, both in terms of sustainable economic development and energy security, as well as in ensuring effective measures against climate change.

Global energy consumption in 2018 increased almost twice the average growth rate since 2010, driven by a sustainable global economy and higher heating and cooling needs in some parts of the world. As a result of higher energy consumption, $\mathrm{CO}_{2}$ emissions increased by $1.7 \%$ in 2018 and reached a historic high of $33.1 \mathrm{Mr}$. At the same time, China, India, and the United States account for $85 \%$ of the net increase in emissions [1].

Figure 1 shows data on $\mathrm{CO}_{2}$ emissions from fossil fuels.

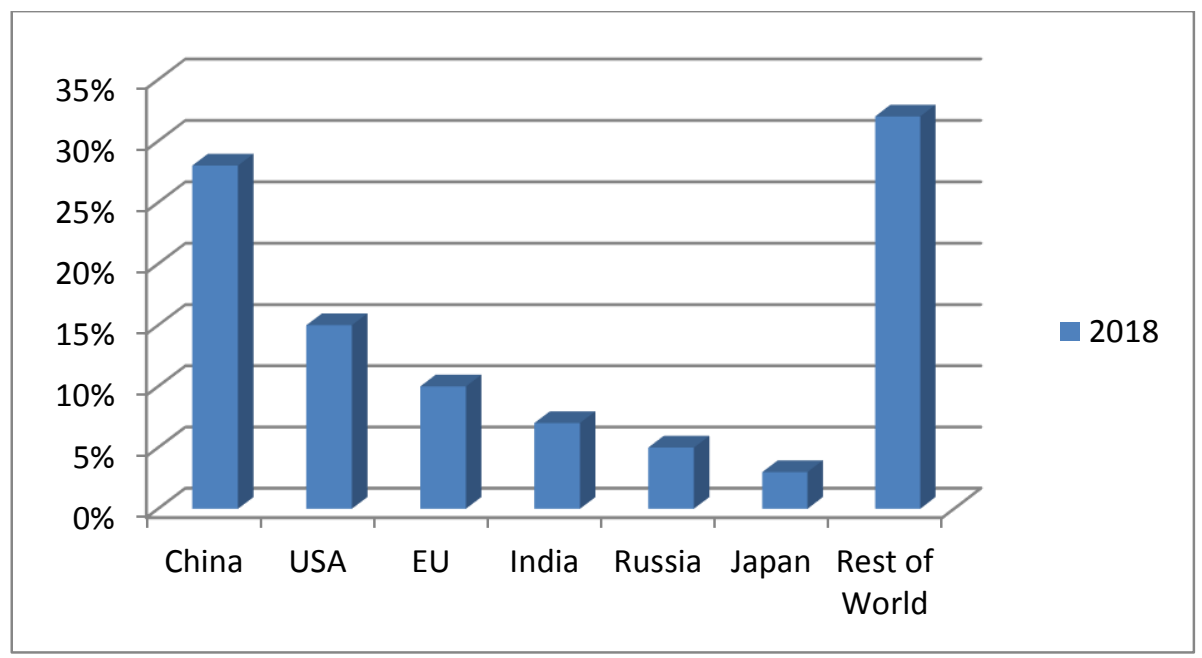

Picture 1. $\mathrm{CO}_{2}$ Emissions from Fossil Fuels (2018) - [2]

Global energy demand and $\mathrm{CO}_{2}$ emissions are expected to increase by about $60 \%$ by 2030 , and more than double by 2050. In 2050, almost 3 times more coal will be consumed than in the early 2000s, gas consumption will increase by $138 \%$, and oil consumption by $65 \%$ [1].

The basis of world energy is currently made up of hydrocarbon reserves (coal, oil, gas), which produce about $70 \%$ of the world's energy (table 1 ).

Kazakhstan has large reserves of energy resources (oil, gas, coal, uranium). About $70 \%$ of Kazakhstan's electricity is generated from coal, $20 \%$ from gas, $9 \%$ from hydroelectric power plants (excluding small hydroelectric plants), and $1.3 \%$ from renewable energy sources (including small hydroelectric plants).

At the same time, the world is at a turning point, when it is necessary to revise the structure of traditional energy based on hydrocarbon sources. In addition to the depletion of these renewable energy resources, the environmental crisis plays a significant role. Annual carbon dioxide emissions increase by an average of 100 tons. Scientists predict that if the critical situation continues at this rate, then humanity faces a global catastrophe. 
Table 1. Electricity Generation Mix 2018

\begin{tabular}{|l|c|}
\hline \multicolumn{1}{|c|}{ Type of energy } & Share, \% \\
\hline Coal & 38.0 \\
\hline Oil & 3.0 \\
\hline Gas & 23.2 \\
\hline Nuclear & 10.2 \\
\hline Renewable Energy (RE) - Total & 25.1 \\
among them: & \\
- Hydro & 15.8 \\
$-\quad$ Wind & 4.8 \\
- Solar & 2.2 \\
$-\quad$ Bio & 2.0 \\
$-\quad$ Geo & 0.3 \\
\hline Other & 0.5 \\
\hline Total & 100 \\
\hline Source: Statistical Review of world Energy 2019 (June 2019) \\
\hline
\end{tabular}

Countries such as India, China use $70-80 \%$ of coal in the country's energy balance, the United States, Japan and Germany-30-40\%. The lowest share of coal (5-15\%) is in England, Canada, Spain, Italy and Ireland.

In November 2016, Kazakhstan became a member of the global movement to prevent global warming as a result of the ratification of the 2015 Paris agreement adopted at the XXI United Nations Conference on climate change. In this regard, the country must meet its obligations to limit/reduce greenhouse gas emissions and report on the results of their achievement every 5 years. Kazakhstan has committed to reducing greenhouse gas emissions by $15 \%$ by 2030 compared to the baseline year of 1990 (emissions were 389 million tons of $\mathrm{CO}_{2}$ equivalent, in 2015 - 301 million tons). By 2030, emissions should not exceed 330 million tons of $\mathrm{CO}_{2}$.

To achieve these goals, the Republic of Kazakhstan uses market mechanisms: the system of trading emission quotas; projects to reduce emissions and absorb greenhouse gases; projects to use renewable energy sources; and the development of the green Finance market.

In 2013, based on the European experience, Kazakhstan launched the national carbon market, an emissions trading system that is the main tool for regulating domestic greenhouse gas emissions and encourages the development of low-carbon technologies and renewable energy sources. In 2016, it was decided to introduce new principles of this mechanism from 2018, which are based on the application of specific greenhouse gas emission factors (benchmarks) on the example of international practice.

Thus, the world community puts forward the priority of expanding the use of renewable and alternative energy sources: wind, solar, water, nuclear and hydrogen technologies.

It was realized that for each object of energy consumption, it is necessary to make a choice and find an individual solution for the heat and power supply system, first of all, the choice between traditional and non-traditional renewable energy sources, which are the basis of alternative (AlE) or innovative energy (InE).

The concept of $A l E$ or $I n E$ includes devices that generate electrical and thermal energy that use other sources of energy (wind power, solar energy, earth heat, etc.) rather than hydrocarbons. Depending on the type of energy source, alternative energy is divided into: wind, small power, solar (helio), energy from the use of industrial and household waste, biomass energy, hydrogen, nuclear, etc. 
In general, there are about 15 types of alternative energy. World practice has accumulated wide experience in the development and implementation of energy-saving renewable environmentally clean technologies.

In a number of advanced countries, programs aimed at developing alternative energy appeared in the 1980s. However, most states began to take serious steps in this direction in the 1990s.

Currently, policy programs aimed at developing alternative energy exist in 66 countries. These include all 27 EU countries, 29 States in America, and 9 provinces in Canada. One of the most important measures was the development of alternative energy standards, which require retail electricity suppliers to use a certain percentage of electricity generated by RES 1. These standards apply in 44 countries, including the United States, the Netherlands, the United Kingdom, Belgium, Denmark, France, Spain, Sweden, and Japan and Australia - [2].

All these measures made it possible to increase the share of renewable sources to $25.1 \%$ in 2018, and up to $35.3 \%$, taking into account nuclear energy (Table 2).

Table 2. RE Share in Electricity Consumption 2018,\% [2,3,4]

\begin{tabular}{|l|c|c|c|c|c|c|}
\hline $\begin{array}{c}\text { Country/type of } \\
\text { RE }\end{array}$ & Solar & Wind & Geothermal & Bioenergy & Hydro & Total \\
\hline Canada & - & 5 & - & 1 & 64 & 70 \\
\hline Sweden & - & 12 & - & 7 & 43 & 62 \\
\hline Denmark & 3 & 39 & - & 17 & - & 59 \\
\hline Portugal & 2 & 22 & - & 6 & 22 & 52 \\
\hline Chile & 6 & 4 & - & 7 & 29 & 46 \\
\hline Germany & 8 & 18 & - & 9 & 3 & 38 \\
\hline Spain & 4 & 18 & - & 3 & 12 & 37 \\
\hline Italy & 7 & 5 & 1 & 6 & 15 & 34 \\
\hline Ireland & - & 27 & - & 3 & 2 & 32 \\
\hline UK & 4 & 16 & - & 10 & 1 & 31 \\
\hline China & 3 & 5 & - & 1 & 17 & 26 \\
\hline France & 2 & 6 & - & 1 & 13 & 22 \\
\hline Japan & 7 & 1 & - & 2 & 8 & 18 \\
\hline USA & 2 & 6 & - & 2 & 7 & 17 \\
\hline India & 2 & 4 & - & 2 & 9 & 17 \\
\hline
\end{tabular}

For example, in China, renewable energy capacity increased by $12 \%$ in 2018 compared to 2017 , as the country continues to implement new projects despite capacity problems and growing debts for the payment of subsidies. Total capacity, including hydropower and biomass, as well as solar and wind power, increased to 728 gigawatts (GWh) by the end of 2018. This represented $38.3 \%$ of China's total installed capacity, which is $1.7 \%$ higher than in 2017 [5].

Renewable energy sources produced more electricity in Germany for the first time than coal and nuclear power combined, according to the latest data. Renewable sources produced $47.3 \%$ of Germany's electricity in the first half of 2019 , while $43.4 \%$ came from coal and nuclear power during this period, according to a report published by the Fraunhofer solar energy Institute (ISE) [6].

Canada is one of the world's leaders in the production and use of energy from renewable sources-hydropower, wind, solar, and biomass - with significant development in geothermal and marine energy, accounting for more than $70 \%$ of Canada's total electricity production in 2018. According to National Energy Board (NEB) data, renewable energy sources such as 
wind, biomass, geothermal and solar energy are projected to reach $12 \%$ of total electricity production by 2035 [7].

In Kazakhstan, the share of renewable energy sources (RES) is only $1.3 \%$. At the same time, it is necessary to note a five-fold increase in RES in the country over the past 5 years. According to international experts, Kazakhstan has taken a leading position in the world in terms of the speed of increasing renewable energy capacity. Currently, there are 74 existing RES facilities with a total capacity of 678.6 megawatts (hydroelectric power station (HPS) 200.3; Wind Power Stations (WPS) -227; Solar power stations (SPS) -250; biogas plant 1.3).

One of the types of alternative energy sources is nuclear power. In the world as a whole, it is $10.2 \%$ (table 1 ), about 450 nuclear reactors are operated in about 30 countries. The largest amount of nuclear energy in 2018 was produced in the United States $(31.4 \%)$, in second place - France (15.3\%), in third place - China (10.9\%), in fourth place - Russia (7.6\%), then - North Korea (3.7\%). Ukraine, Germany, England, Sweden, Spain - from 3.1\% to $2.1 \%$ [8].

Kazakhstan ranks first in the world in uranium production (39\%), ahead of Canada and Australia. At the same time, the only 350 megawatt (MW) nuclear power plant with a fast neutron reactor operated in Aktau in 1973-1999. For a long time there have been discussions about the need to build a new nuclear power plant in Kazakhstan with a capacity of $600 \mathrm{MW}$ in the area of lake Balkhash. The main problems are the high cost of the future nuclear power plant and safety problems. Accidents that occurred at nuclear power plants (Chernobyl, Fukushima) showed the danger of radioactive contamination after its release into the environment. Ukraine additionally spends budget funds under the program Of the state Agency of Ukraine for management of the exclusion zone "Ukraine's Contributions to the Chernobyl Fund", as well as in the EBRD's nuclear safety accounts and other programs. In addition, the service life of nuclear power units is 30 years. In Ukraine, there are reactors that have completed their service life. Significant investments are needed to upgrade and replace them. Japan also suffered huge losses caused by the accident at the nuclear power plant, which has already exceeded $\$ 100$ billion. in addition, the annual cost of maintaining the reactor and ensuring safety even after the final shutdown is millions of dollars. In addition, storing and controlling thousands of tons of highly active waste from reactors for hundreds of years also requires significant financial resources [9].

In our opinion, it is necessary to hold a referendum on such important issues related to the security of not only a particular region, but also the country as a whole. For example, in Germany, it was decided to gradually abandon nuclear energy and switch to "green" energy. Therefore, for the first time, $47.3 \%$ of the electricity consumed was obtained from renewable sources, and $43.4 \%$-from coal and nuclear power plants. After the accident at the Fukushima Daiichi nuclear power plant, Japan set a goal of tripling electricity generation from renewable energy sources by 2030 compared to 2010 [10]. In our opinion, this is the right strategy.

Thus, when making decisions about electricity supply, it is necessary to take into account the positive and negative aspects of various sources of electricity.

In this regard, we have conducted research that results in the systematization of factors (table 3), problems that affect the effectiveness of alternative energy sources and the development of recommendations for supporting electricity producers based on RES, taking into account international experience.

According to expert estimates, the energy potential of RES in Kazakhstan is very significant, for example, the potential of wind power alone in Kazakhstan is about 920 billion $\mathrm{kWh}$ per year, which is about 10 times more than today our entire country consumes electric energy. The hydro potential of Kazakhstan is estimated at 62 billion $\mathrm{kW}$, which is $70 \%$ of the current consumption in the country. The potential of solar energy in the southern regions of the country is about 2500-3000 thousand solar hours per year, which is quite a lot and 
allows the southern regions of the country to be competitive with the sunniest countries in the world.

Table 3. Classification of factors affecting the effectiveness of alternative energy sources

\begin{tabular}{|c|c|c|c|}
\hline $\begin{array}{c}\text { Climate } \\
\text { conditions }\end{array}$ & $\begin{array}{c}\text { Technical and } \\
\text { economic } \\
\text { conditions }\end{array}$ & $\begin{array}{l}\text { Environmental } \\
\text { conditions }\end{array}$ & $\begin{array}{l}\text { Geographic } \\
\text { conditions }\end{array}$ \\
\hline $\begin{array}{l}\text { - wind speed, m / s; } \\
\text { - the grade of } \\
\text { openness of the } \\
\text { terrain; } \\
\text { - insolation, W / } \\
\mathrm{m}^{2} \text {; } \\
\text { - availability of } \\
\text { natural and artificial } \\
\text { watercourses; } \\
\text {-availability of } \\
\text { geothermal sources, } \\
\text { etc. }\end{array}$ & $\begin{array}{l}\text { - the price of the } \\
\text { equipment; } \\
\text { - cost of } \\
\text { transportation and } \\
\text { installation of } \\
\text { equipment; } \\
\text { - equipment service } \\
\text { life; } \\
\text { - payment for } \\
\text { environmental } \\
\text { pollution; } \\
\text { - state of power } \\
\text { generating } \\
\text { equipment; } \\
\text { - efficiency } \\
\text { coefficient; } \\
\text { - electricity tariff } \\
\text { by traditional } \\
\text { sources, etc. }\end{array}$ & $\begin{array}{l}\text { - impact on animals } \\
\text { and birds from the } \\
\text { rotation of the wind } \\
\text { turbine blades; } \\
\text { - effects on marine } \\
\text { animals from } \\
\text { electromagnetic } \\
\text { fields; } \\
\text { - the amount of } \\
\text { harmful emissions } \\
\text { and greenhouse effect } \\
\text { from traditional } \\
\text { energy sources, etc. }\end{array}$ & $\begin{array}{l}\text { - distance from } \\
\text { the centralized } \\
\text { power supply } \\
\text { system; } \\
\text { - the distance } \\
\text { from suppliers of } \\
\text { fossil fuels; } \\
\text { - minimum } \\
\text { distance from the } \\
\text { installation to } \\
\text { settlements, etc. }\end{array}$ \\
\hline
\end{tabular}

Source: compiled by the authors on the basis of generalization of information

In our view, climate conditions and the existing potential of the region are important.

Based on numerous studies, Kazakhstan has almost inexhaustible potential for solar, wind, geothermal energy and bioenergy.

Therefore, the prospects for the development of the renewable energy industry in the country are great. In addition, the geographical factor also contributes to the development of RES in Kazakhstan: a large territory (2. 725 million $\left.\mathrm{km}^{2}\right)$ and low population density (6.9 people $/ \mathrm{km}^{2}$ ). Therefore, no electricity tariffs can compensate for the costs associated with the power supply of remote villages. In addition, Kazakhstan's climate conditions contribute to significant heat consumption for heat supply needs. In this regard, it is more efficient to use alternative sources in such regions, primarily wind and solar energy.

A similar geographical location, in our opinion, is on the territory of Alaska, USA, which has an area of 1.718 million $\mathrm{km}^{2}$, the population is 710 thousand people, of which approximately 239 thousand people live in rural communities of the state. Over the past two years, 66 projects have been implemented, which saved about 30 million gallons of diesel fuel in 2016. As you know, electricity costs for rural Alaskans are among the highest in the United States [11]. In just three years, the wind farm eliminated the need for 3 million gallons of diesel fuel in Kodiak. In addition to wind energy, Alaska's great potential is solar energy, biomass, biofuels, geothermal energy, tides, and other natural resources. The difficulties of widespread 
introduction of alternative energy sources are associated with the high cost of their installation (three times more than the cost of diesel generation) - [12].

Technical and economic factors (table 3) have a significant impact on the rate of development of alternative energy sources. The main issue is attracting investment from various sources. This process is impossible without the political will and support of the state. In addition, the state can influence the formation of tariffs for alternative energy sources, the provision of subsidies from the budget, loans at lower interest rates, tax and other economic benefits, etc. There are also government programs that promote the development of alternative energy market infrastructure, including design standards, the procedure for obtaining permits, licensing, creating a joint enterprise, etc.

In Kazakhstan, the increase in the growth rate of RES was facilitated by the holding of the specialized exhibition EXPO 2017, which was attended by 118 countries, international organizations and corporations that presented their latest developments and technologies in the field of future energy. The exhibition gave an impetus to the regions of the country to implement the technologies demonstrated at EXPO 2017, which contributed to the emergence of a new sector in the country - "green" energy. The expert group selected 105 foreign and 28 domestic technologies. The search for investors is conducted by the international center for "green" technologies and investment projects. In this regard, agreements have been reached with public and private organizations in Japan, South Korea, the United States, the United Arab Emirates, China and a number of European countries on active cooperation and implementation of joint projects. It should be noted that all RES projects in the Republic of Kazakhstan are carried out only at the expense of own and borrowed funds of investors and funds from the national budget are not spent. At the same time, investment preferences are provided in accordance with the Business Codex on the basis of an investment contract concluded between the investment Committee of the Ministry of industry and infrastructure development of the Republic of Kazakhstan and the legal entity implementing the project. Favorable investment conditions attracted large oil companies to the" green" energy sector of Kazakhstan - Shell, ENI, Total, which in the competitive struggle win the right to implement projects in Kazakhstan. 2018 selection for the implementation of projects takes place through auctions. This allows us to gradually reduce the impact on tariffs for end-users from the introduction of renewable power sources. International auctions in 2018-2019 were held in electronic format for projects with a total capacity of 1,205 MW. A total of 138 companies from 12 countries participated in the auction. Participants were offered bids for projects with an installed capacity of about 3,900 MW, which is 3.2 times higher than the demand. Based on the results of the auctions, 30 companies signed contracts with the unified electricity buyer Settlement and financial center (SFC) for 15 years for a total capacity of $804 \mathrm{MW}$ and 12 companies are at the stage of signing contracts with the SFC for a total capacity of $163 \mathrm{MW}$.

In total, since the operation of the SFC (2013), about 406 billion tenge has been attracted to the RES sector from investors from 10 countries, as well as large financial organizations (EBRD, ABD, KDB). According to experts, the constructed objects will be transferred to the budget of about 81 billion tenge. In addition, Kazakhstan engineers, builders and support staff are involved in the construction of RES facilities.

Thus, the legislation of the Republic of Kazakhstan defines support measures in the form of guaranteed purchase of electricity from renewable energy facilities by a single electricity buyer - a Settlement and financial center under an agreement drawn up for 15 years at an auction rate, as well as ensuring the connection of the object to the electric networks. At the same time, annual indexation of tariffs is provided, taking into account inflation and changes in the dollar exchange rate. In addition, energy producers are exempt from paying for the services of energy transmission organizations for the transmission of electric energy. In accordance with the law, the state also provides individual consumers located in non- 
electrified localities with a $50 \%$ subsidy from the cost of a $5 \mathrm{~kW}$ plant produced in Kazakhstan. For active involvement of households, small and medium-sized businesses in the use of distributed generation, as is observed in different countries, it is necessary to improve the rules for economic stimulation of the population to use "green" energy for their own needs. It is also necessary to resolve issues related to the sale of excess electricity (solar, etc.) to the network (net metering), as well as the use of financial instruments (preferential tariffs, "green" certificates, tax incentives, etc.).

An important step in enhancing the implementation of renewable energy projects and helping to improve the ecology of large cities is the use of "green" finance - investments and other financial instruments aimed at environmentally friendly, energy-efficient and lowcarbon projects. Traditionally in the world, "green" Finance exists in the form of "green" bonds, preferential lending or special subsidies for renewable energy projects.

The first green bonds were issued in 2007 by the European investment Bank. Currently, the EIB is the largest Issuer of green bonds issued in 11 currencies. Currently, 160 projects have been funded in almost 50 countries. The total investment in projects is 80 billion euros [13].

The popularity of bonds is related to their advantages over loans: a long maturity, a wide investor base (except for banks, financial institutions can provide borrowed funds), and no collateral is required. Issuers can be governments, banks, municipalities, or corporations.

Currently, China remains one of the leading players in the Green bond market. In 2018, the issue of bonds exceeded $\$ 30$ billion and the country ranked second in the world. American issuers published $\$ 34.1$ billion of green bonds, France in third place ( $\$ 14.2$ billion) [14].

In Kazakhstan, the creation of the Astana International financial center (AIFC) contributes to the activation of green Finance by providing a platform for issuing green bonds to companies engaged in energy-efficient projects.

Tax exemption is used as a tax incentive measure in many countries. Tax incentives can be applied for investment, production or consumption of electricity produced from renewable energy sources, as well as for the purchase and installation of equipment. In some countries, a carbon tax is used to reduce the consumption of fossil fuels [10].

Despite the achievements in the use of renewable energy, India and China continue to use $70-80 \%$ of coal in the energy balance. At the same time, these countries have significant RES potential. In addition, these are the two most populous countries in the world, whose economic development, including the energy sector, is developing at a rapid pace. According to experts, in order to achieve a balance between the need for electricity and its production, India should pay special attention to nuclear energy. Currently, nuclear energy accounts for only $2 \%$ of the total electricity supply generated by seven nuclear power plants [15].

To speed up the process of replacing traditional energy sources with renewable resources, it is necessary to identify problems (barriers) that hinder this process [16]:

- Political and regulatory barriers. In countries where there is no state support, there are no legal and regulations that support the use of renewable energy sources, investors are not interested in investing capital because of the lack of incentives and high risks.

- Technical barrier. Some, especially developing countries, lack the technology and infrastructure to develop alternative energy. Due to the low General level of education and lack of qualified personnel (for example, in sub-Saharan Africa), some countries are not willing to import equipment and technologies for the use of renewable energy sources. In addition, imported equipment is expensive, which affects the cost of electricity, which will become almost inaccessible to the poor. When equipment fails, there are often no spare parts or personnel to maintain and repair it. There are big problems in the transmission of renewable energy through networks (this applies especially to wind energy), which is associated with energy losses. Therefore, investors are not willing to invest because of the high risks. 
- Social and cultural barriers. For example, the reluctance of households to adopt renewable energy sources for fear of unreliability is one of the reasons for the refusal to adopt renewable energy technologies in some countries. In addition, the lack of knowledge about the benefits of renewable energy sources, especially among rural communities, hinders the spread of the concept of renewable energy. It is necessary to raise the level of awareness of all segments of the population about RES, to raise their General social and cultural level.

- Financial and economic barriers. Start-up capital, transaction costs, economic situation, and availability of incentives and subsidies are important factors that determine the pace of implementation of renewable energy technologies. Initial capital expenditures for renewable energy sources are relatively high compared to traditional energy sources, which in turn increases the cost of producing renewable energy. The economic aspects of RES implementation were described in detail above. Therefore, governments should support investment in renewable energy to accelerate the commercialization of technologies. The insufficient credit base for the acquisition of sustainable energy technologies and high interest rates on loans are also a significant obstacle to the development of renewable energy sources. Most traditional power plants are known to have been built with substantial subsidies. However, in many countries where renewable energy technologies are not well developed, a small number of financial institutions (both public and private) are willing to provide significant loans for renewable energy projects.

Market barriers. Initial investment costs for renewable energy systems are usually high. Consequently, market prices for these systems remain high and inaccessible to many potential consumers, especially in developing countries.

Other factors that make renewable energy technologies less competitive or unavailable in markets include the lack of successful and reproducible renewable energy business models for turning small projects into commercial enterprises; the lack of a market for renewable energy; and high and fluctuating renewable energy prices in some countries, such as China. Since the renewable energy market is limited, its development is also limited. This is because when there are problems with the sale of a product, people do not invest enough money in its development. In this case, when it comes to renewable energy sources, it is obvious that most people are not interested in purchasing or developing them.

Geographical and environmental barriers. Geographical location and natural conditions in the region can be a kind of barrier to the development of renewable energy sources (table 3). For example, the distribution of solar energy on the Earth's surface depends on geographical location, so in some countries, such as India, where solar and wind energy are sporadic, solar energy is also sporadic. This, therefore, restricts the population of such regions from using solar energy, since it will not be reliable.

Overcoming the above barriers will allow countries to increase the share of RES in total energy consumption, as well as significantly reduce $\mathrm{CO}_{2}$ emissions, which is provided for by the 2015 Paris agreement. This trend is already being observed. Growth in global oil demand slowed in 2018 as higher oil prices partially offset sustained economic activity around the world.

Kazakhstan is investing heavily in the development of renewable energy. This is facilitated by state support and legislation, significant potential, and adopted target indicators. It is planned to increase the share of RES in the total volume of electricity production to $3 \%$ in 2020 , to $6 \%$ in $2025,10 \%$ by 2030 , and by 2050 renewable and alternative energy sources should account for at least $50 \%$ of the total energy consumption.

The new BloombergNEF (NEO) 2019 energy forecast notes that the introduction of renewable energy sources is happening so fast that it will put the world on track to limit global temperature increases to $2^{\circ} \mathrm{C}$ by 2030 . New wind and solar power plants, often with batteries, are projected to produce energy more cheaply (without subsidies) than existing coal and gas power plants almost worldwide by 2030. As a result, the role of coal in the global 
energy mix will fall from $37 \%$ currently to just $12 \%$ by 2050 , while oil as an energy source will be virtually eliminated, as wind and solar will grow from $7 \%$ of generation today to $48 \%$ by 2050 . The contribution of hydropower, natural gas, and nuclear power will remain approximately the same as a percentage [17].

\section{Conclusion}

Global electricity consumption is projected to increase over the next two decades. At the same time, the global community is concerned about global climate change, rising prices for fossil fuels, and political instability in the main supplier countries. In this regard, RES has become an important object of research to increase their share in the total energy consumption. The widespread use of renewable energy sources and increasing competitiveness is also hindered by continued subsidies and other measures of state support for oil production and refining industries. In this regard, it is necessary to take into account factors that affect the effectiveness of RES implementation, as well as barriers that prevent the acceleration of the process of replacing traditional sources with RES (political and regulatory barriers, technical, socio-cultural, financial and economic, market, geographical and environmental barriers).

\section{References}

1. Global Energy and $\mathrm{CO}_{2}$ Status Report. International Energy Agency, 28 (2018).

2. BR Statistical Review of World Energy 2019 (June 2019) at p. 57. See J. Olivier and J. Peters. Trends in Global $\mathrm{CO}_{2}$.

3. International Energy Agency. Electricity Information 2019 (September 2019).

4. International Energy Agency.Renewables Information 2019 (August 2019).

5. Reporting by David Stanway and Beijing Monitoring Desk. Reuters. Environment (January 28, 2019).

6. Rachel Cordery. Power Technology (24 July 2019).

7. Export.gov. Canada Country Commercial Guide (30 September 2019).

8. Statista. World nuclear power consumption by country 2018. Published by T. Wang (Jun 17, 2019).

9. Еспресо TV.Украинская Ассоциация возобновляемой энергетики. Что дешевле «чистая» или «грязная» энергия.

10. Shahrouz Abolhosseini, Almas Heshmati. Discussion Paper No. 8182. The main Support Mechanisms to Finance Renewable Energy Development (May 2014), pp. $1-20$.

11. Mottl J. Special Section Energy \& Power, pp. 34-39 (2017).

12. Kruge M.A. International Energy Agency (IEA), Power Systems Program. Report IEA PVTS T1-26:2015, pp.1-15 (2015).

13. European Investment Bank celebrates green bonds' $10^{\text {th }}$ anniversary. UniCredit, pp.1-11 (28 June 2017).

14. China Green Bond Market, pp.1-20 (2018).

15. Jack Unwin. The top seven nuclear power plants in India. Power Technology (26.02.2019).

16. Dorcas Kariuki. Barriers to Renewable Energy Technologies Development. The Official publication of the American Energy Society published by De Gruyter (2018).

17. Mike Scott. Wind and Solar power set to dominate power mix by 2050, as coal continues to decline. Forbes (Jun 24, 2019). 